\title{
An Empirical Study on the Influence of the Economic Cooperation between the Mainland of China and Hong Kong on Economic Growth and Industrial Development of HK since the Return to China
}

\author{
Qi Zou \\ School of Economics, Jinan University, Guangzhou, China \\ Email: qiqi_zou@sina.com
}

Received 5 January 2016; accepted 23 January 2016; published 26 January 2016

Copyright (C) 2016 by author and Scientific Research Publishing Inc. This work is licensed under the Creative Commons Attribution International License (CC BY). http://creativecommons.org/licenses/by/4.0/

(c) (i) Open Access

\begin{abstract}
This paper presents the economic cooperation between Mainland China and Hong Kong in the past years since Hong Kong's return in commodity trade, investment, and service trade, and then calculates the trade combined degree. Based on the data from 1994 to 2013, by the empirical methods of unit root tests, co-integration analyses, and Granger causality tests, this paper studied the influence of the commodity trade, investment, service trade on economic growth and the industrial structure of Hong Kong, and draw the conclusion: the goods imports from Hong Kong to the mainland of China don't show effect on the second industry, so as the service imports on GDP and the tertiary industry. The commodity trade, investment and service exports from Hong Kong to the mainland of China have the positive effect on the GDP growth. The commodity imports of Hong Kong, and the investment from the mainland of China promote the development of the tertiary industry in Hong Kong; then the development of the third industry will promote the service exports from Hong Kong to the mainland of China.
\end{abstract}

\section{Keywords}

The Return of Hong Kong, Economic Cooperation, The Mainland of China, Hong Kong, Effect 


\section{Introduction}

Since the return to China in 1997, with the preferential policy support from our country and the unique geographical advantage, Hong Kong strengthens her status as the global centre of trade, finance, commerce and telecommunications. Since Hong Kong's return, the economy grows fast. According to the latest statistics from the World Bank, in 2014, GDP came to 290.9 billion dollars, grew by 3.5\% a year on average, with the GDP per capita to 40,196.5 dollars. What's more, the share of value-added of the service sector in the GDP was 92.7\%, which was higher than most of the other countries in Asian.

The mainland of China and Hong Kong have been the most important economic and trade partners to each other for a long time. And the cooperation between them is increasingly close under the concept of "one country, two systems" since Hong Kong's return. In June 2003, they signed the Closer Economic Partnership Arrangement (CEPA), clearing the institutional obstacles in the trade cooperation. In the same year, as a part of CEPA, Mainland China operated the Individual Visit Scheme, promoting the economic and trade cooperation with Hong Kong. Therefore, it is of great significance to study the influence of the economic cooperation between the mainland of China and Hong Kong for their future development.

Most of the related empirical research at home and abroad focused on the relationship between Chinese economic growth and her cooperation with other countries, with little about the influence of the cooperation on HK. Xiao Hong [1] found that the trade did have a strong positive correlation with Hong Kong's economic growth by checking the contribution rate of Hong Kong's economic growth brought by the trade. Chen Guanghan [2] found that Hong Kong gave a good economic performance indicated by a causal relationship between economic growth and international trade and between economic growth and industrial structure, which was mostly due to the policy "One country, two systems".

In view of descriptions above, this paper studied the influence of the commodity trade, investment, service trade on economic growth and the industrial structure of Hong Kong based on the data from 1994 to 2013, to hold the tendencies, find the rules, and make recommendations.

\section{Summary of the Economic and Trade Cooperation between Mainland China and Hong Kong}

As Hong Kong is a key trade link between the mainland of China and the other countries, the mainland of China with rapid economic growth has been the major market and an important source of capital for Hong Kong. The implementation of CEPA, which is consists of the policies on commodity trade, investment, service trade promote the cooperation between the two places based on the principle of "mutual benefit, complementary advantages and common prosperity".

\subsection{The Trade between Mainland China and Hong Kong}

\subsubsection{The Merchandise Trade}

With the rapid development of the economy of the mainland of China, especially after the accession to the WTO, the international trade of Mainland China has been constantly increasing opening-up, and the economic partnership between Hong Kong and the mainland of China is more and more closer. For Hong Kong, the proportion of goods imports from the mainland of China to all the goods imports of Hong Kong and the domestic exports of goods to the mainland of China to all the domestic exports of goods of Hong Kong keep rising steadily over the years. In $2014,42 \%$ of the domestic goods exports were exported to the mainland of China, and $47.1 \%$ of the goods imports were from the mainland of China. As one of the most important trade forms in Hong Kong, the re-export trade plays an unique role in the economy. The mainland of China was the major source as well as the major destination of Hong Kong's re-exports of goods. Conclusion from the change tendency, the merchandise trade with the mainland of China fall off in the years around 1997, 2002 and 2008 tracked with the decline in the total trade of Hong Kong for this period affected by the Asian financial crisis, SARS epidemic and American financial crisis in the relevant years [3]-[6]. All in all, the merchandise trade between Mainland China and Hong Kong is much closer since the return of Hong Kong. The merchandise trade statistics between Mainland China and Hong Kong are shown in Table 1.

\subsubsection{Trade in Services}

Figure 1 presents the values of exports and imports of services of Hong Kong with the mainland of China from 
Table 1. The merchandise trade statistics of Hong Kong with the mainland of China (\$ million).

\begin{tabular}{|c|c|c|c|c|c|c|c|c|c|}
\hline \multirow[b]{2}{*}{ Year } & \multicolumn{3}{|c|}{ Domestic exports } & \multicolumn{3}{|c|}{ Re-exports } & \multicolumn{3}{|c|}{ Imports } \\
\hline & Amount & $\begin{array}{l}\text { As percentage of } \\
\text { the total } \\
\text { domestic exports } \\
\text { (\%) }\end{array}$ & $\begin{array}{l}\text { Change } \\
\text { over the } \\
\text { preceding } \\
\text { year (\%) }\end{array}$ & Amount & $\begin{array}{l}\text { As percentage } \\
\text { of the total } \\
\text { domestic } \\
\text { exports (\%) }\end{array}$ & $\begin{array}{c}\text { Change over } \\
\text { the preceding } \\
\text { year (\%) }\end{array}$ & Amount & $\begin{array}{l}\text { As percentage } \\
\text { of the total } \\
\text { domestic } \\
\text { exports (\%) }\end{array}$ & $\begin{array}{c}\text { Change over } \\
\text { the preceding } \\
\text { year (\%) }\end{array}$ \\
\hline 1998 & 56,066 & 29.8 & -12.2 & 407,366 & 35.1 & -8.2 & 580,614 & 40.6 & -4.6 \\
\hline 1999 & 50,414 & 29.6 & -10.1 & 399,188 & 33.9 & -2.0 & 607,546 & 43.6 & 4.6 \\
\hline 2000 & 54,158 & 29.9 & 7.4 & 488,823 & 35.1 & 22.5 & 714,987 & 43.1 & 17.7 \\
\hline 2001 & 49,547 & 32.3 & -8.5 & 496,574 & 37.4 & 1.6 & 681,980 & 43.5 & -4.6 \\
\hline 2002 & 41,374 & 31.6 & -16.5 & 571,870 & 40.0 & 15.2 & 717,074 & 44.3 & 5.1 \\
\hline 2003 & 36,757 & 30.2 & -11.2 & 705,787 & 43.5 & 23.4 & 785,625 & 43.5 & 9.6 \\
\hline 2004 & 37,898 & 30.1 & 3.1 & 850,645 & 44.9 & 20.5 & 918,275 & 43.5 & 16.9 \\
\hline 2005 & 44,643 & 32.8 & 17.8 & 967,923 & 45.8 & 13.8 & $1,049,335$ & 45.0 & 14.3 \\
\hline 2006 & 40,268 & 29.9 & -9.8 & $1,115,942$ & 48.0 & 15.3 & 1,192,953 & 45.9 & 13.7 \\
\hline 2007 & 40,610 & 37.2 & 0.8 & $1,267,723$ & 49.2 & 13.6 & $1,329,652$ & 46.4 & 11.5 \\
\hline 2008 & 34,758 & 38.3 & -14.4 & $1,335,687$ & 48.9 & 5.4 & $1,410,735$ & 46.6 & 6.1 \\
\hline 2009 & 26,672 & 46.2 & -23.3 & $1,236,577$ & 51.3 & -7.4 & $1,249,374$ & 46.4 & -11.4 \\
\hline 2010 & 31,223 & 44.9 & 17.1 & 1,566,999 & 52.9 & 26.7 & $1,529,751$ & 45.5 & 22.4 \\
\hline 2011 & 30,699 & 46.8 & -1.7 & $1,716,656$ & 52.5 & 9.6 & $1,696,807$ & 45.1 & 10.9 \\
\hline 2012 & 26,027 & 44.2 & -15.2 & 1,831,732 & 54.3 & 6.7 & $1,840,862$ & 47.1 & 8.5 \\
\hline 2013 & 24,784 & 44.8 & -4.8 & $1,924,463$ & 54.9 & 5.1 & 1,942,131 & 47.8 & 5.5 \\
\hline 2014 & 23,195 & 42.0 & -6.4 & $1,955,821$ & 54.1 & 1.6 & 1,986,964 & 47.1 & 2.3 \\
\hline
\end{tabular}

Source: The Census and Statistics Department of HK SAR.
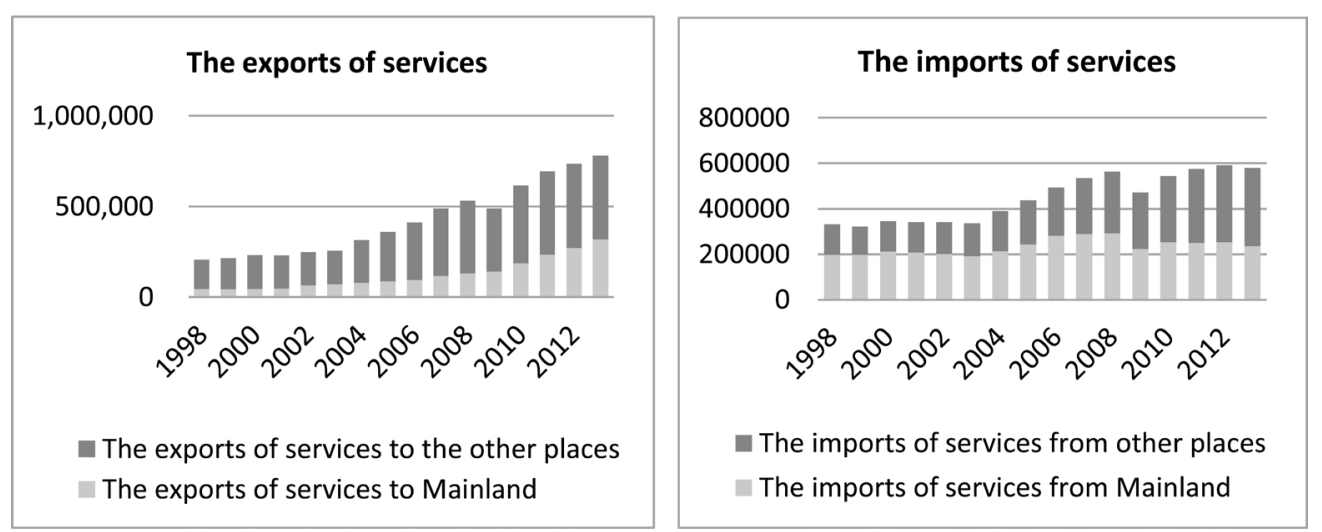

Source: The Census and Statistics Department of HK SAR.

Figure 1. The values of exports and imports of services of Hong Kong with Mainland China (\$ million).

1998 to 2013. On the whole, in 2013, the imports of services from the mainland of China valued at $\$ 235.9$ billion, contributed $40.7 \%$ to the total imports of services value of Hong Kong, increasing $23.6 \%$ compared to the number in 1998. What's more, the exports of services to the mainland of China amounted to $\$ 317.1$ billion in 2013, which is seven times that of 1998 , representing $40.6 \%$ of the value of the total exports of services of Hong Kong in that year. As it is reflected in the chart, with the increasingly opening-up of Mainland China in the international trade, the growth of the service exports to the mainland of China from Hong Kong is much rapider than that of the service imports from the mainland of China, which is because that the highly developed service industry in Hong Kong is more competitive than the incomplete market-led one in the mainland of China. In 
2012, the trade in services of Hong Kong with the mainland of China was in surplus. As the time changes, the annual growth rate of service input and output in Hong Kong in the bilateral trade between Mainland China and Hong Kong presents a certain degree of fluctuation, but in most of the years, the service trade between the two places has a positive growth. In detail, as it's shown in Figure 2, in 2002, the total exports of services of Hong Kong to the mainland of China had significant growth influenced by Chinese accession to the WTO, while in this period around 2003, the service imports from the mainland of China decreased due to the import restrictions of Hong Kong because of the SARS. In 2004 after the signature of CEPA, the bilateral service trade between the mainland of China and Hong Kong grew rapidly, then influenced by the global financial crisis in 2008, its growth rate curve has a downward trend.

Besides, under the individual visit scheme, a large number of tourists from the mainland of China travel to Hong Kong, the ratio of the exports of services involving in the tourism to total bilateral trade increased from $22.1 \%$ in 1999 to $75.2 \%$ in 2013, with the exports of travel services being the most important component. Figure 3 presents the components of exports of services of Hong Kong in relation to the mainland of China for 2013.

\subsubsection{The Analysis on the Trade Combined Degree of Hong Kong}

The trade combined degree measures the depth of the relationships between the trading partners, the greater the value, the closer the trade connection between the two countries. It is a comprehensive indicator. Its formula is: $\mathrm{TCDab}=(\mathrm{Xab} / \mathrm{Xa}) /(\mathrm{Mb} / \mathrm{Mw})$, of which, TCDab is short for the trade combined degree of country a to country b, $\mathrm{Xab}$ represents the exports of country a to country b, Xa indicates the total exports of country a, Mb and Mw represent the total imports of country $b$ and the world separately. According to the definition above, the two countries connected closely by the economic trade while TCDab is greater than 1 , otherwise, the trade is not so

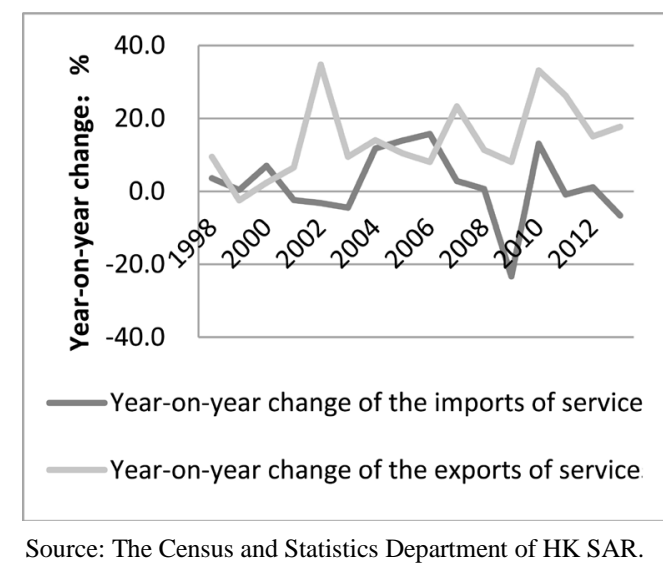

Figure 2. The year-on-year changes of imports and exports of services of Hong Kong with Mainland China \%.

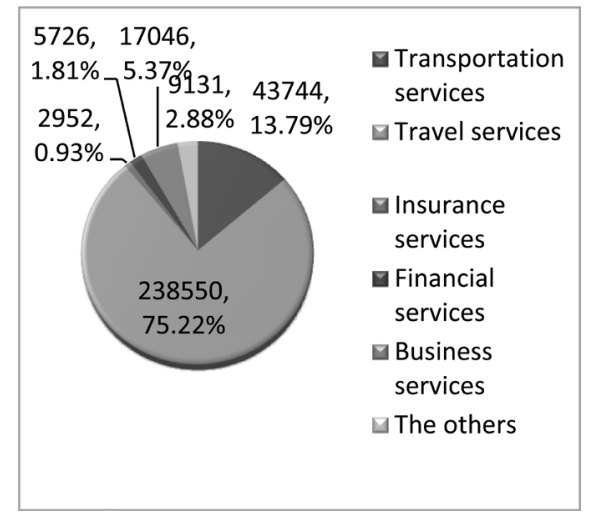

Source: The Census and Statistics Department of HK SAR.

Figure 3. The components of exports of services of Hong Kong with Mainland China in 2013. 
frequency. The trade combined degrees of Mainland China and Hong Kong are shown in Table 2.

As the time changes, the Trade Combined Degrees present a downward trend, the TCD of Hong Kong to the mainland of China decreased from 10.53 to 4.21, and became less volatility ever since, the TCD of Mainland China to Hong Kong fell to 4.28 from 15.72. This is mainly because that with the rapid development of the economy of the mainland of China, the expansion of trade openness, the economic trade of Mainland China grew fast, at the same time, the pro portion of the trade related to Mainland China in the world increased rapidly. Even though the imports of Hong Kong to the mainland of China increased by $79 \%$ times, the share of Hong Kong's exports to the mainland of China in the value of its total exports rose from $25 \%$ to $41 \%$, the trade combined degree fell as the denominator grew. It suggests that the international trade of Mainland China with the countries from all over the word grew more rapidly than that with Hong Kong over the years, businessmen in Hong Kong are faced with fiercer competition in the trade with Mainland China. Even so, the trade combined degrees are far more than 1, which suggests that Hong Kong still has a close trade communication with Mainland China. What's more, the TCD of Hong Kong to America and Japan are 1.19, 1.09 respectively in 2013, much less than that to Mainland China as 4.21.

\subsection{Direct Investment between the Mainland of China and Hong Kong}

Influenced by the Asian financial crisis, the SARS, the inward and outward direct investment of Hong Kong decreased in the period around, as well as the direct investment with Mainland China. After the implementation of CEPA in 2004, which smooth away the systematic obstacles in mutual investment, the proportions of the inward DI from the mainland of China to Hong Kong's inward DI and the outward DI to the mainland of China to Hong Kong's outward DI have increased smoothly. In these years, the mainland of China was not only the major destination for Hong Kong's outward DI, but also the most important source for Hong Kong's inward DI. At the end of 2014, the position of Hong Kong's outward DI to the mainland of China amounted to $\$ 4560$ billion, with a share of $40.5 \%$ of the total position of Hong Kong's outward DI. On the other hand, the position of Hong Kong's inward DI from the mainland of China was 3493.5 billion in 2014, 17 times that of 1998, accounting for about $30.1 \%$ of the total. Table 3 presents the position of Hong Kong's direct investment with the mainland of China.

\section{The Empirical Study on the Influence of the Economic Cooperation between the Mainland of China and Hong Kong}

\subsection{The Target Selection and the Data Processing}

\subsubsection{Theoretical Basis and the Choice of the Dependent Variables}

1) The economic growth

The impact of trade on economic growth is discussed in all the stages of international trade theory development. In the comparative advantage theory and the factor endowments theory, it is concluded that through the optical allocation of resources, productivity is improved through international trade, so as to enhance the welfare of trade countries. Foreign trade multiplier theory emphasize on the department consumption from the increased exports, which will increase the income and consumption of the relevant departments through the industrial chain of the national economy, and finally realize the double growth of the national income and national economy. The new trade theory explains the import as the main factor for technological progress, which is an important reason for the improvement of labor productivity. Starting with the analysis of trade terms, the contrary view is that, for the developing countries which export the primary products, the international trade can even lead to the increase in poverty; on the other hand, one of the earliest theories on the relationship between FDI and the economic growth of the host country is the "dual gap model", FDI helps to make up for the shortage of funds, as well as the gap of deposits and foreign currency, thereby promoting the economic growth and structural transfer of the host country. The endogenous growth theory which was proposed by Romer emphasizes the role of technology diffusion on the economic growth in small countries.

2) The industrial development

The international trade theory and the international investment theory, to a certain degree, has been involved in the influence of trade and international capital movements on the industrial upgrading of the investment and the host country. The Japanese economist Akanmatsu put forward the "flying geese model" on the industrial 
Table 2. The trade combined degrees of Mainland China and Hong Kong.

\begin{tabular}{ccccccccc}
\hline Year & 1998 & 1999 & 2000 & 2001 & 2002 & 2003 & 2004 & 2005 \\
\hline TCD of Hong Kong to Mainland China & 10.53 & 9.09 & 7.53 & 7.16 & 6.71 & 5.79 & 4.93 & 4.78 \\
TCD of Mainland China to Hong Kong & 15.72 & 16.54 & 14.36 & 13.11 & 11.13 & 9.35 & 8.27 & 7.67 \\
Year & 2006 & 2007 & 2008 & 2009 & 2010 & 2011 & 2012 & 2013 \\
TCD of Hong Kong to Mainland China & 4.21 & 4.28 & 4.17 & 4.24 & 3.84 & 4.02 & 4.07 & 4.21 \\
TCD of Mainland China to Hong Kong & 7.09 & 6.41 & 6.19 & 6.10 & 5.35 & 5.08 & 4.70 & 4.28 \\
\hline
\end{tabular}

Source: Calculation based on the statistics from the Census and Statistics Department of HK SAR and UNCTAD.

Table 3. The position of Hong Kong’s direct investment with the mainland of China (\$ billion).

\begin{tabular}{ccccccc}
\hline Year & $\begin{array}{c}\text { Outward DI to } \\
\text { the mainland of China }\end{array}$ & $\begin{array}{c}\text { Outward DI of } \\
\text { Hong Kong }\end{array}$ & The ratio (\%) & $\begin{array}{c}\text { Inward DI from } \\
\text { the mainland of China }\end{array}$ & $\begin{array}{c}\text { Inward DI of } \\
\text { Hong Kong }\end{array}$ & The ratio (\%) \\
\hline 1998 & 534.3 & 1668.8 & 32.0 & 205.9 & 1627.2 & 12.7 \\
1999 & 608.1 & 2448.1 & 24.8 & 805.6 & 3026.5 & 26.6 \\
2000 & 991.2 & 2956.9 & 33.5 & 1095.0 & 3394.5 & 32.3 \\
2001 & 812.4 & 2711.6 & 30.0 & 928.0 & 3128.1 & 29.7 \\
2002 & 812.4 & 2391.1 & 34.0 & 571.1 & 2456.9 & 23.2 \\
2003 & 899.6 & 2691.2 & 33.4 & 747.2 & 2823.3 & 26.5 \\
2004 & 1161.4 & 3173.2 & 36.6 & 979.5 & 3319.7 & 29.5 \\
2005 & 1425.9 & 3691.7 & 38.6 & 1222.0 & 3828.9 & 31.9 \\
2006 & 2055.7 & 5289.0 & 38.9 & 1967.6 & 5469.9 & 36.0 \\
2007 & 3363.8 & 8028.1 & 41.9 & 3677.3 & 8955.3 & 41.1 \\
2008 & 2552.7 & 5955.5 & 42.9 & 2250.9 & 6070.6 & 37.1 \\
2009 & 2682.2 & 6508.6 & 41.2 & 2603.6 & 7013.3 & 37.1 \\
2010 & 3014.7 & 7338.6 & 41.1 & 3127.1 & 8299.4 & 37.7 \\
2011 & 3346.4 & 7946.4 & 42.1 & 3042.8 & 8377.0 & 36.3 \\
2012 & 3671.1 & 9010.2 & 40.7 & 3568.3 & 9646.6 & 37.0 \\
2013 & 3952.3 & 9619.7 & 41.1 & 3341.6 & $10,482.9$ & 31.9 \\
2014 & 4560.0 & $11,246.9$ & 40.5 & 3493.5 & $11,602.9$ & 30.1 \\
\hline
\end{tabular}

Source: The Census and Statistics Department of HK SAR.

development, he thinks that countries should adhere to the export-oriented strategy, actively promote trade, investment and financial liberalization, and develop export-oriented economy. The marginal industry theory proposed by Kojima pointed out that FDI can not only promote the development of labor intensive industries, but also promote the upgrading of the industrial structure of home and the host country. In the "National Competitiveness", Potter incorporated the service trade competitiveness into the research category, he also mentioned that in trade and investment, the pressure from the demand side can encourage enterprises to pursue the technological progress, and the country achieve the industrial upgrading ultimately.

Therefore, this paper selects the gross domestic product (GDP), the output values of the second and the third industry (ind, sev) respectively as the dependent variables, to study the influence of the economic cooperation on economic growth and industrial development of HK. In order to eliminate the influence of price changes, GDP and output value are divided by the relevant implicit price deflator.

\subsubsection{The Selection of the Independent Variables}

As the description above, the economic and trade cooperation between Hong Kong and the mainland of China, cover the trade in goods, the trade in services and the direct investment. To measure the economic and trade relationship objectively, the domestic exports of goods to the mainland of China (ex), the imports of goods from the mainland of China (im), imports and exports of services of Hong Kong in the bilateral trade (imse, exse), Hong Kong's position of direct investment from the mainland of China (fdi) are chosen as the independent va- 
riables in the article. To eliminate the influence of price changes, the quantities are revalued at base-year prices.

Considering data availability and the influence of the degree of freedom, in this paper, the sample interval in the empirical analysis is 1994-2013, the data is all from the census and statistics department of HK SAR. All variables are the logarithmic form of the actual value allowing for heterogeneity.

\subsection{Model Specifications}

By the empirical methods of unit root tests, co-integration analyses, Granger causality tests, this paper study the relationship between Mainland China-Hong Kong economic cooperation and economic growth, industrial development of Hong Kong. In the analysis of the long-run equilibrium relationships between related variables by co-integration tests, this paper build multiple models, studying the effect of the merchandise trade, investment, service trade respectively, including the effect on economic growth, industrial upgrading, by which we could learn the effect of each separately and clearly, avoid the correlation between variables leading to incorrect conclusions, increase the degree of freedom to improve the accuracy of the empirical analysis under the condition of a given sample range.

\subsection{The Stationary Tests}

In the analysis of time series, it requires the stationary test to avoid spurious regression, and this article adopt the augment Dickey-Full test. The test results are shown in Table 4.

In Table 4, we can see that all the variables are nonstationary in the 5\% level of significance, but the firstorder differences are stationary in the $5 \%$ significance level, which indicates that all variable time series are integrated of order I (1). Because nonstationary time series cannot adopt the method of ordinary least squares, we examined the existence of co-integration using the co-integration test, namely the existence of long-run equilibrium relationships between the variable series.

\subsection{The Cointegration Tests}

The common methods of cointegration tests are the Engle-Granger test and the Johansen-Juselius maximum likelihood method. This article adopts the Johansen cointegration test, which is applicable to the small sample. The optimal lag length is determined by the AIC and SC criteria of unconstrained VAR model. When there is contradiction between results above, LR (Likelihood Ratio) is used to determine the lag length. But in small samples, the criteria above may be not reliable, the paper calculate the modificatory AIC and test the residuals then, and take the economic meaning into consideration to seek a balance between dynamics and the degree of freedom. Again, the Johansen test is the cointegration analysis for the VAR model after first-order difference, so its lag length takes lag length of VAR model minus 1 (Table 5 and Table 6).

As it's shown in Table 5, there is not cointegration relationship between lnind and lnim, lngdp and lnimse, or lnsev and lnimse, which suggests that the empirical test hasn't prove the existence of the influence of Hong Kong's merchandise imports on its second industry, imports of services on its economic growth and the tertiary

Table 4. The results of the ADF test.

\begin{tabular}{|c|c|c|c|c|c|c|c|c|c|}
\hline Series & $\begin{array}{l}\text { Include in test } \\
\text { equation }(c, t, n)\end{array}$ & t-statistic & $\begin{array}{l}5 \% \text { critical } \\
\text { value }\end{array}$ & $\begin{array}{l}\text { Stationary or } \\
\text { nonstationary }\end{array}$ & Series & $\begin{array}{l}\text { Include in test } \\
\text { equation }(c, t, n)\end{array}$ & t-statistic & $\begin{array}{c}5 \% \text { critical } \\
\text { value }\end{array}$ & $\begin{array}{l}\text { Stationary or } \\
\text { nonstationary }\end{array}$ \\
\hline lngdp & $(\mathrm{c}, \mathrm{t}, 1)$ & -2.2229 & -3.6908 & nonstationary & D (lngdp) & $(\mathrm{c}, 0,1)$ & -3.7215 & -3.6908 & stationary \\
\hline lnind & $(\mathrm{c}, \mathrm{t}, 1)$ & 0.6321 & -3.6908 & nonstationary & D (lnind) & $(\mathrm{c}, \mathrm{t}, 0)$ & -4.5984 & -3.6908 & stationary \\
\hline lnsev & $(\mathrm{c}, \mathrm{t}, 1)$ & -2.8179 & -3.6908 & nonstationary & D (lnsev) & $(\mathrm{c}, \mathrm{t}, 1)$ & -4.4517 & -3.7105 & stationary \\
\hline $\operatorname{lnfdi}$ & $(\mathrm{c}, \mathrm{t}, 1)$ & -1.6379 & -3.6908 & nonstationary & D (lnfdi) & $(\mathrm{c}, \mathrm{t}, 4)$ & -4.0282 & -3.7912 & stationary \\
\hline lnex & $(\mathrm{c}, \mathrm{t}, 0)$ & -2.3709 & -3.6736 & nonstationary & D (lnex) & $(\mathrm{c}, \mathrm{t}, 1)$ & -4.3572 & -3.7104 & stationary \\
\hline $\operatorname{lnim}$ & $(\mathrm{c}, \mathrm{t}, 3)$ & -1.9433 & -3.6736 & nonstationary & D (lnim) & $(\mathrm{c}, \mathrm{t}, 0)$ & -4.8992 & -3.6908 & stationary \\
\hline lnexse & $(\mathrm{c}, 0,0)$ & 1.3187 & -3.0299 & nonstationary & D (lnexse) & $(\mathrm{c}, 0,0)$ & -3.5163 & -3.0404 & stationary \\
\hline lnimse & $(\mathrm{c}, 0,0)$ & -2.4209 & -3.0299 & nonstationary & D (lnimse) & $(\mathrm{c}, 0,0)$ & -3.5375 & -3.0403 & stationary \\
\hline
\end{tabular}

Note: 1. D( ) denotes the first-order difference; 2 . In (c,t,n), c,t represent the intercept and trend respectively, $\mathrm{n}$ indicates the lag length, which is determined by the AIC criterion. 
Table 5. The results of Johansen cointegration tests.

\begin{tabular}{|c|c|c|c|c|c|c|}
\hline Variables & Lag length & Hypothesized No. of CE(s) & Eigenvalue & Trace statistic & $5 \%$ critical value & Probablity \\
\hline \multirow{3}{*}{ lngdp, lnex, lnim } & \multirow{3}{*}{0} & $r=0$ & 0.869468 & 50.97790 & 24.27596 & 0.0000 \\
\hline & & $\mathrm{r} \leq 1$ & 0.468278 & 12.29128 & 12.32090 & 0.0506 \\
\hline & & $\mathrm{r} \leq 2$ & 0.015143 & 0.289923 & 4.129906 & 0.6514 \\
\hline \multirow{2}{*}{ lngdp, lnfdi } & \multirow{2}{*}{2} & $r=0$ & 0.578326 & 22.37637 & 20.26184 & 0.0252 \\
\hline & & $\mathrm{r} \leq 1$ & 0.364113 & 7.696477 & 9.164546 & 0.0943 \\
\hline \multirow{2}{*}{ lngdp, lnexse } & \multirow{2}{*}{0} & $r=0$ & 0.775406 & 28.40913 & 12.32090 & 0.0001 \\
\hline & & $r \leq 1$ & 0.001755 & 0.033377 & 4.129906 & 0.8812 \\
\hline \multirow{2}{*}{ lngdp, lnimse } & \multirow{2}{*}{0} & $r=0$ & 0.317058 & 7.245565 & 15.49471 & 0.5493 \\
\hline & & $\mathrm{r} \leq 1$ & $1.74 \mathrm{E}-08$ & $3.31 \mathrm{E}-07$ & 3.841466 & 0.9997 \\
\hline \multirow{2}{*}{ lnind, lnex } & \multirow{2}{*}{1} & $r=0$ & 0.593392 & 17.02365 & 15.49471 & 0.0292 \\
\hline & & $r \leq 1$ & 0.044817 & 0.825337 & 3.851466 & 0.3636 \\
\hline \multirow{2}{*}{ lnind, lnim } & \multirow{2}{*}{0} & $r=0$ & 0.343641 & 9.245916 & 15.49471 & 0.3431 \\
\hline & & $r \leq 1$ & 0.063475 & 1.246006 & 3.841466 & 0.2643 \\
\hline \multirow{3}{*}{ lnsev, lnex, lnim } & \multirow{3}{*}{1} & $r=0$ & 0.819632 & 42.14957 & 35.01090 & 0.0074 \\
\hline & & $\mathrm{r} \leq 1$ & 0.404375 & 11.31992 & 18.39771 & 0.3622 \\
\hline & & $r \leq 2$ & 0.104830 & 1.993343 & 3.841466 & 0.1580 \\
\hline \multirow{2}{*}{ lnsev, lnfdi } & \multirow{2}{*}{2} & $r=0$ & 0.670336 & 20.19002 & 15.49471 & 0.0091 \\
\hline & & $r \leq 1$ & 0.075005 & 1.325429 & 3.841466 & 0.2496 \\
\hline \multirow{2}{*}{ lnsev, lnexse } & \multirow{2}{*}{0} & $r=0$ & 0.769840 & 28.12626 & 12.32090 & 0.0001 \\
\hline & & $r \leq 1$ & 0.011284 & 0.215615 & 4.129906 & 0.6993 \\
\hline \multirow{2}{*}{ lnsev, lnimse } & \multirow{2}{*}{0} & $r=0$ & 0.278793 & 6.333253 & 15.49471 & 0.6561 \\
\hline & & $\mathrm{r} \leq 1$ & 0.006479 & 0.123502 & 3.841466 & 0.7253 \\
\hline
\end{tabular}

Table 6. Conintegration equations and the log likelihood.

\begin{tabular}{|c|c|c|c|}
\hline \multicolumn{2}{|c|}{ Economic growth } & \multicolumn{2}{|c|}{ Upgrading industrial structure } \\
\hline $\begin{aligned} \operatorname{lngdp}= & 0.197 \operatorname{lnex}+0.905 \operatorname{lnim} \\
& (3.0406)(17.8610)\end{aligned}$ & Log likelihood $=98.1015$ & $\begin{array}{c}\text { lnind }=0.903 \operatorname{lnex} \\
\quad(6.5955)\end{array}$ & Log likelihood $=53.18124$ \\
\hline $\begin{array}{c}\text { lngdp }=0.238 \operatorname{lnfdi}+10.923 \\
(8.0458)(26.7819)\end{array}$ & Log likelihood $=32.2361$ & $\begin{aligned} \operatorname{lnsev}= & 1.041 \operatorname{lnim}-0.541 \operatorname{lnex} \\
& (9.5062)(-7.4565)\end{aligned}$ & Log likelihood = 99.6814 \\
\hline \multirow[t]{2}{*}{$\begin{array}{c}\text { lngdp }=1.675 \text { lnexse } \\
(31.4023)\end{array}$} & Log likelihood $=59.4302$ & $\begin{array}{l}\text { lnsev }=0.267 \operatorname{lnfdi} \\
\quad(12.2896)\end{array}$ & Log likelihood $=33.87457$ \\
\hline & & $\begin{array}{c}\text { lnsev }=1.804 \ln \text { exse } \\
(24.9109)\end{array}$ & Log likelihood $=52.31973$ \\
\hline
\end{tabular}

Note: $t$ value are shown in brackets.

industry in the trade with the mainland of China during the period. More than $70 \%$ of the commodities imported from the mainland of China are consumer goods, then electric machinery, equipment and utensils account for only about $20 \%$, which could be the reason why there is not long-run equilibrium relationship between imports and output value of the secondary industry. The influence of imports of services on the economic growth will be affected by many factors, including the economic system, the trade policy, the economic stage, the trade strategy and so on, in addition, more than $50 \%$ of the input of services from the mainland of China are manufacturing services. Besides, the other groups of variables have the long-term cointegration relationships in the $5 \%$ level of significance, namely long-run equilibrium relationships.

In the economic and trade cooperation between the mainland of China and Hong Kong, commodity trade, direct investment from the mainland of China to Hong Kong, exports of services have a positive effect on economic growth of Hong Kong. Every one percent increase of service output will boost GDP to increase by 1.67 
percentage, which is a great influence on the economic growth. Every additional unit increase for product export can promote economic growth with 0.197 units in the long run and with relatively minimal impact. In addition, for the import of products, FDI, every unit change will cause GDP to change with 0.905 units and 0.238 units respectively. This is in line with our expectations. The great technological spillover effects, economic scale effects, employment effects of service trade may make it contribute more to economic growth. In the trade between the two places, the import trade has a more significant contribution to economic growth, and the reason can be analyzed from the mechanism from which import trade promotes the economic growth. As we all know, the resource of a certain region is limited, they are unlikely to meet all the requirements of the industry, the imports of the deficient resource from the mainland of China play an important role in improving the profitability of enterprises, promoting the development of new industries, optimizing the industrial structure, improving added value of the products, and promoting the economic growth of Hong Kong eventually.

The exports of services to the mainland of China, the imports of goods and the direct investment from the Mainland China all contributed to the development of the tertiary industry. And domestic exports of goods to the mainland of China promoted the development of the secondary industry. In detail, the output value of the second industry will increase $0.9 \%$, the output of the tertiary industry will decrease $0.54 \%$ when the exports of goods to the mainland of China increase 1\%. Every additional unit increase in goods exports from Mainland China will promote the output of the tertiary industry to increase 1.0441 unit. What's more, in the long term, the output value of the tertiary industry will increase by 0.26 and 1.80 units respectively if the direct investment or the exports of services increased a unit.

\subsection{The Granger Causality Tests}

The result of the cointegration test just shows that there is a long-term equilibrium relationship between the variables, but whether the relationship forms a causal relationship needs further verification. This article adopts the Granger causality test, the lag length is determined by the Akaike information criterion (AIC). The results are shown in Table 7.

In the trade between the mainland of China and Hong Kong, imports and domestic exports of goods, exports of services of Hong Kong, the direct investment from the mainland of China are the Granger reasons of the economic growth of Hong Kong. Then there is a significant two-way Granger causality between the domestic exports of goods and the output of the second industry, which suggests that the domestic exports of goods promoted the development of the second industry, and the development of the second industry cause more goods to be exported to the mainland of China. The import and export trade between the two places, the direct investment from the mainland of China to Hong Kong are the Granger reasons of the growth of the output of the service sector, which conforms with results of the cointegration tests. What's more, as the development of the service sector is the Granger reason of the exports of services to the mainland of China, the development of the service sector promote the exports of services to the mainland of China.

Table 7. Results of the granger causality tests.

\begin{tabular}{|c|c|c|c|c|c|c|c|c|c|}
\hline Dependent variable & df & Excluded & Chi-sq & Probability & Dependent variable & df & Excluded & Chi-sq & Probability \\
\hline \multirow{2}{*}{ lngdp } & \multirow{2}{*}{1} & $\operatorname{lnim}$ & 3.694788 & $0.0546^{*}$ & \multirow{2}{*}{ lnsev } & \multirow{2}{*}{2} & $\operatorname{lnex}$ & 7.263814 & $0.0265^{* *}$ \\
\hline & & lnex & 5.132213 & $0.0235^{* *}$ & & & $\operatorname{lnim}$ & 4.250262 & $0.1194^{*}$ \\
\hline \multirow{2}{*}{$\operatorname{lnim}$} & \multirow{2}{*}{1} & lngdp & 3.417323 & $0.0645^{*}$ & \multirow{2}{*}{ lnex } & \multirow{2}{*}{2} & Lnsev & 3.071410 & 0.2153 \\
\hline & & lnex & 6.229299 & $0.0126^{* *}$ & & & $\operatorname{lnim}$ & 0.539544 & 0.7636 \\
\hline \multirow{2}{*}{$\operatorname{lnex}$} & \multirow{2}{*}{1} & lngdp & 1.841986 & 0.1747 & \multirow{2}{*}{$\operatorname{lnim}$} & \multirow{2}{*}{2} & lnsev & 0.935340 & 0.6265 \\
\hline & & $\operatorname{lnim}$ & 0.202294 & 0.6524 & & & lnex & 2.082603 & 0.3530 \\
\hline lngdp & 3 & $\operatorname{lnfdi}$ & 7.085101 & $0.0692^{*}$ & lnsev & 3 & lnfdi & 8.910887 & $0.0305^{* *}$ \\
\hline $\operatorname{lnfdi}$ & 3 & lngdp & 4.625708 & 0.2013 & $\operatorname{lnfdi}$ & 3 & lnsev & 2.875805 & 0.4112 \\
\hline lngdp & 1 & lnexse & 3.664158 & $0.0556^{*}$ & lnsev & 1 & lnexse & 1.856337 & 0.1730 \\
\hline lnexse & 1 & lngdp & 0.853443 & 0.3556 & lnexse & 1 & lnsev & 3.190050 & $0.0741^{*}$ \\
\hline lnind & 2 & lnex & 7.469517 & $0.0013^{* *}$ & & & & & \\
\hline lnex & 2 & lnind & 7.079224 & $0.0013^{* *}$ & & & & & \\
\hline
\end{tabular}




\section{The Conclusions and Policy Recommendations}

Based on the analyses above, we can draw conclusions as follows: in the economic and trade cooperation between Mainland China and Hong Kong, the imports and exports of goods, the direct investment from the mainland of China to Hong Kong, and the exports of services of Hong Kong have a positive effect on its economic growth; the long-term elastics are: $0.91,0.20,0.24,1.67$, and the exports of services have a greater influence on the economic growth than others. The imports of goods and the direct investment also promoted the development of the tertiary industry in Hong Kong; elastics are 0.27 and 1.04 respectively; with the development of the tertiary industry, more services were exported to the mainland of China. And there is a two-way Granger causality between the domestic exports of goods and the output of the second industry.

The general recommendations presented in this paper are to make full use of the existing favorable conditions, further deepen economic and trade cooperation between the two places, and promote realizing the strategic target of co-prosperity. The details are as follows:

1) To further optimize the quality of the direct investment from the mainland of China to Hong Kong. As the analyses above, the effect of the direct investment on the economic growth and industrial development of Hong Kong is less than imports of services. There are various reasons for this problem, but the inefficient use of the direct investment must be one of them. Therefore, we should not only continue to expand the scale of the investment in both places, but also attach great importance to improve the efficiency of the investment utilization, and strengthen the association among enterprises from Hong Kong and Mainland China in the future.

2) To optimize the merchandise trade structure, actively encourage enterprises to import or export the products with high technological contents. At present, the trade in goods between the two places grows steadily. In the future, we should improve the added value of products in trade allowing for the active effect of the imports and exports on economic growth.

3) To expand imports and exports of services, improve the structure of service trade actively. As the results above, the development of the service sector promotes the exports of services to the mainland of China, and the exports of services play an important role in promoting the economic growth. Therefore, it's important for Hong Kong's economic growth to cultivate and develop service industry, and continue to increase service exports. On the other hand, the influence of the imports of services from the mainland of China hasn't shown up in the empirical analysis, but with the development of new service industry, the influence of service imports will increase. The government should open markets of services further then. Besides, the tourism output shows a large increase in the constitute of service trade for the two places; it requires the government to vigorously develop innovative tourism projects and commodities on the basis of maintaining and improving the traditional labor intensive service trade.

\section{References}

[1] Xiao, H. and Yang, F.M. (2010) An Empirical Analysis of the Rate of Contribution of Hong Kong's Economic Growth Brought by Chinese Mainland-Hong Kong Trade. International Economics and Trade Research, 1, 19-23.

[2] Zhang, G.N. and Chen, G.H. (2009) International Trade, Economic Growth and Industrial Structure: The Successful Combination of "One Country, Two Systems" and Reform and Opening-Up Policy. International Economics and Trade Research, 1, 4-8.

[3] Huang, Q.B. and Jiang, L. (2008) An Empirical Analysis of the Trade Relationship between Chinese Mainland and Hong Kong: Based on the Theory of Co-Integration and Granger Causality Test. International Economics and Trade Research, 10, 33-37.

[4] Huang, Q.B. and Fan, H.M. (2010) Foreign Trade, Economic Growth and Upgrading of Industrial Structure: An Empirical Test Based on China, India and Asian "Four Little Dragons. Journal of International Trade, 2, 38-44.

[5] The Research Group from the State Information Center (2012) Report on the Economic and Trade Cooperation between Chinese Mainland and Hong Kong for Fifteen Years. Review of Economic Research, 68, 3-37.

[6] Yang, F.M. and Xiao, H. (2010) The Influence of Service Trade on Economic Growth in Hong Kong: An Empirical Analysis Based on the Time Series Data of 1980-2009. International Economics and Trade Research, 12, 35-40. 